Interjú Balogh Jánossal, Nagy Istvánnal és Túrós Andrással

\title{
Külterületek biztonsága, környezetünk védelme 2019-2020
}

Az Agrárminisztérium és az Országos Polgárőr Szövetség együttmüködésében, az Országos Rendőr-főkkapitányság szakmai támogatásával és felügyeletével megvalósuló program

Lajosmizsén került megrendezésre 2019. november 9-én az a szakmai rendezvény, amelynek témája az Agrárminisztérium és az Országos Polgárőr Szövetség együttmüködésében, az Országos Rendőr-fökapitányság szakmai támogatásával és felügyeletével a 2019-2020. év között megvalósuló projekt programindító eseménye volt. Az elöadások során elhangzott, hogy milyen nagy jelentősége van az összefogásnak egy olyan történelmi pillanatban, amikor a globális kihívások, a klímaváltozás következtében felértékelődnek Magyarország természeti erőforrásai, termőföldjei, ivóvízkészlete, valamennyi természet adta kincse, amely az itt élő emberek jólétének záloga. A különböző területeken, szinteken müködő intézmények szakemberei, vezetői felismerték, hogy a kitüzött célok hatékonyabban, sikeresebben megvalósíthatók egy jól szervezett, előkészített összefogás keretében. Különösen nagy érdeklődésre tarthat számot, amikor egy közös program különböző résztvevői a saját szemszögükből láttatva mutatják be annak részleteit. Ennek érdekében kérdeztük a projektről és annak részleteiről mindhárom szervezet vezetőjét, akik örömmel tettek eleget megkeresésünknek.

Elsőként Túrós Andrást, az Országos Polgárőr Szövetség elnökét kérdeztük az összefogásról, akivel Hornyik Zsuzsanna beszélgetett.

Tisztelt Elnök Úr! A 2019. november 9-én megrendezett Külterületek biztonsága, környezetünk védelme 2019-2020 programinditó konferencián kiderült, hogy az Országos Polgárör Szövetségnek kiemelt szerep jutott nemcsak a program elökészitésében, de végrehajtásában is. Mi is a közös program elözménye, célja és mi indokolta annak elinditását?

Az előzmények kapcsán egészen 2009-ig kell visszamennünk az időben. Tíz évvel ezelőtt Pintér Sándor belügyminiszter megbízott azzal, hogy tájékozódjunk Magyarország különböző régióiban, hogy milyen a lakosság biztonságérzete, milyen problémákat látnak a helyi lakosok a közbiztonságot illetően, és 
milyen javaslataik vannak azok kezelésére, megoldására. 2010-re ez a felmérés elkészült Borsod-, Szabolcs, Heves- és Somogy-megye vonatkozásában, ahol találkoztunk a helyi lakosokkal és a települések vezetőivel is. Általános véleményként fogalmazódott meg a megkérdezettek részéről, hogy nem kielégítő a közbiztonság a külterületeken. Sok volt a lopás, a rongálás, erdőirtás, a szántóföldi termények eltulajdonítása, a szőlőskertek lerombolása. A másik előzménye a mostani programnak, hogy a tapasztalt negatív jelenségek megismerését követően, azokra tekintettel, öt évvel ezelőtt az Országos Polgárőr Szövetség meghirdetett egy hasonló programot, a külterületek biztonságának a programját, amely egyszerüen abban merült ki, hogy meghatározta a polgárőrök számára azt, hogy szolgálati óráik 25-30\%-át külterületeken teljesítsék. Az előzmények között említeném meg rendőri pályafutásom során aziránt szerzett tapasztalataimat is, hogy a külterületeken elkövetett büncselekmények nem kaptak kellő figyelmet a rendészeti szervek részéről. Személy szerint engem a lakosság részéről megfogalmazódott kritika motivált leginkább abban, hogy valamit tenni kell a helyzet megoldása érdekében. A 2015-ös program rendkívül sikeresnek bizonyult. Érezhetően visszaszorult a bünözés, a jogsértések száma a külterületeken, a polgárörök puszta jelenléte idézte elő a kedvező irányú változást. Több száz tettenérésben, elfogásban is részt vettek a kollégák.

A program jelenlegi célja a viszonylag elfogadható biztonság stabilizálása, elsősorban a falopások, erdei rongálások megelőzése, valamint az, hogy a polgárőrség a megvalósítás élére állva alakítson ki egy virtuális külterületi biztonsági hálót, elsősorban az alföldi megyékben és azokon a helyeken, ahol jelentős a tanyavilág. Ehhez társul további járulékos célként a környezetkárosítás megelőzése és a környezeti értékek megelőző védelme.

Hogyan határozták meg a programban résztvevö szervezetek a végrehajtás idôtartamát?

Az Agrárminisztériummal abban állapodtunk meg, hogy a meghirdetett program időtartama bő egy év legyen, de ez nem jelenti azt, hogy az 2020. év végén befejeződne. A program időtartama alatt már idén december, január hónapban előkészítő előadások, felkészítések kezdődnek. Mivel idényjellegü jogsértésekről van szó, minden évszakhoz köthető valamilyen külterületi jogsértési tendencia, ezekben az időszakokban összehangoltan, nagy létszámú polgárőr állománnyal próbáljuk a területeket ellenőrizni. Többek között ez is benne foglaltatik a 2020-as munkatervben. Nagy polgárör demonstrációkkal is próbáljuk javítani a külterületek biztonságát.

Kik vesznek részt az összefogás során a program megvalósitásában?
Az Országos Polgárőr Szövetség részéről legalább tízezer polgárőr vesz részt a program megvalósításában. Mivel a Polgárőrség szervezi és áll az élén a programnak, elvárás a helyi polgárőrvezetők felé, hogy koordinálják a végrehajtást, valamint a külterületeken lévő un. alternatív rendészeti szervek képviselőit is bevonják. Így különösen, az Agrárminisztérium kérésének megfelelően, a mezőőröket kell megszólítani, munkájukban támogatni a polgárőr jelenléttel, továbbá valamennyi természetvédelmi őr, halőr, vadőr tevékenységét is erősíteni. A kapcsolatfelvétel a helyi vadásztársaságokkal, a földtulajdonosokkal és gazdákkal is megtörtént. Általános tapasztalat, hogy a gazdák nagy része mástól várja a biztonságot, a nagy gazdaságok pedig védik saját vagyonukat, ugyanis olyan hatalmas értékek halmozódtak fel, hogy vagyonőröket, fegyveres őröket alkalmaznak, de ezek inkább objektum védelemre korlátozódnak. A polgárőrök megszólítják a gazdákat is, erkölcsi, anyagi támogatást kérnek a közbiztonság érdekében folytatott tevékenységükhöz, és szerencsére elmondható, hogy a földtulajdonosok szívesen támogatják az egyesületeket, örömmel fogadják az együttműködés ezen módját.

Mi az Országos Polgárőr Szövetség szerepe a program végrehajtásában? Az Országos Polgárőr Szövetség a gazdája a programnak, az elnökség alkotta meg a programot egyeztetve az Országos Rendőr-főkapitányság vezetőjével, a szakmai ajánlásokat, elvárásokat is az elnökség fogalmazta meg. Tulajdonképpen a Polgárör Szövetség feladata a program meghirdetése, koordinációja és a végrehajtáshoz szükséges feltételek megteremtése. A Polgárőr Szövetség kezdeményezte az Agrárminisztériumnál a program beindítását és szervezetünk javaslatára támogatta negyven millió forinttal a Minisztérium a program elindítását.

Mi várható a most meghirdetett program végrehajtását követően, lesz-e folytatás? Ma még nem látjuk a most induló program hatásait, de ettől függetlenül vannak elképzeléseink a folytatást illetően. Tekintettel arra, hogy a program egésze nemcsak a külterületek biztonságára fókuszál, hanem a környezetünk védelmével is foglalkozik, továbbá a nyitórendezvényen is elhangzott, hogy a Szövetség az ország-fásítási programhoz csatlakozik azáltal, hogy minden polgárőr fejenként öt-öt fa ültetését vállalja a helyi önkormányzatokkal, erdőgazdaságokkal a 2020. és 2021. évben, elmondhatjuk, hogy a 2020. év végével nem fejeződik be a program, folytatódik az azt követő években is. Ismerve a polgárörök lelkes hozzáállását, biztosan kijelenthetem, hogy ennek a programnak a megvalósítása is várhatóan százszázalékos lesz, az eddigi polgárơr akciók végrehajtásához hasonlóan. Amennyiben a közös értékelést követően kiderül, hogy a programnak van létjogosultsága, természetesen folytatódik ezen okból kifolyólag is. Annál 
is inkább valószínú a folytatás, mert egy olyan területre hirdette meg a programot a Polgárör Szövetség, amely eddig nem volt kezelve. Ma Magyarországon a települések biztonsága olyan szintet ért el, hogy a polgárőrségnek van kapacitása arra, hogy a külterületek közbiztonságával foglalkozzon. A külterületek biztonságának javítása és a környezetünk védelme nagyon fontos célkitüzések, és egyre több polgárőr van, aki szívesen csatlakozik a meghirdetett célok megvalósításához és én ennek szívből örülök.

\section{A következőkben álljon itt Balogh János r. altábornaggyal, az Országos Rendőr-főkapitányság vezetőjével készített interjúnk, amelyből a rendőr- ség szemszögéből ismerhetjük meg a programot és annak a hivatásos állo- mányra jutó feladatait.}

Tisztelt Főkapitány Úr! A 2019. november 9-én megrendezett Külterületek biztonsága, környezetünk védelme 2019-2020 programinditó konferencián Ön is elöadást tartott, amelyböl kiderült, hogy már régóta szoros együttmüködés jellemzi a rendörséget és a polgárörséget. Ennek is köszönhetöen lényegesen javultak a bünügyi statisztikák. A most meghirdetett projekt kapcsán szeretnénk néhány kérdést feltenni, amelyeket Túrós Andrásnak, az Országos Polgárőr Szövetség elnökének is feltettünk és Nagy István minisztert is megkerestük. Mi is a közös program elözménye, célja és mi indokolta annak elinditását?

A rendőrség és a polgárőrség kapcsolata harminc évre nyúlik vissza, egészen az Országos Polgárőr Szövetség megalakulásának pillanatáig, amely bátran tekinthető a mostani program előzményének. Nagyon megtisztelő, hogy a Polgárőr Szövetség elnöke, Túrós András egy előadáson megjegyezte, még mindig érzik, hogy fogjuk a kezüket, de már nem olyan viszonylatban, mint a kezdetekkor, hanem most már partnerinek mondható ez a kapcsolat. Nagy örömünkre kölcsönös támogatás jellemzi a jelenlegi együttmüködést. Ma már mindenki számára elfogadott tény, hogy a polgárőrök a közterületek biztonságának fenntartása érdekében állandóan jelenlévő szereplők, és nagyon sok helyen ki tudják egészíteni a rendőrség munkáját. Olyan időszakokban, olyan helyeken tudnak fizikai jelenlétet biztosítani, amelyre a rendőrség nem képes, köszönhetően a Polgárőr Szövetség közel 65ezres létszámának. Ez majdnem a duplája a rendőrség állományának. Ezért, ahol nem szükséges a tényleges rendőri felügyelet, ott a polgárőrök maradéktalanul el tudják látni a közbiztonság fenntartását, és az ahhoz kapcsolódó egyéb megelőző tevékenységeket is. Ahogyan azt a lajosmizsei konferencián is elmondtam, a jelenlegi program tulajdonképpen egy régi jól müködő kapcsolat térbeli kiterjesztése, amely nem jelenti azt, hogy a rendőrség ne lett volna jelen eddig is a külterületeken, csak ez most központi helyre került. Szerencsére mára már kijelenthető, hogy a települések közbiztonsága elérte azt az elfogadható szintet, amely lehetővé tette, hogy a figyelem a külterületek felé is irányuljon. Valójában a külterületeken is jelentős mértékú a büncselekmények számának csökkenése és összességében elmondható, hogy minden tendencia javulást mutat, viszont vannak olyan jelenségek - többek között a környezetkárosítás, illegális hulladéklerakás, rongálás -, amelyekre a mennyiségi adatok okán is jobban oda kell figyelnünk, másrészt a felszabaduló, a településekről átirányított kapacitásnak köszönhetően megvalósíthatónak látszik az egyenszilárdság a települések és a külterületek közbiztonsága tekintetében. Engem személy szerint is nagyon zavar a külterületen zajló illegális hulladéklerakás, és nagyon örülök annak, hogy egyre többen vannak ezzel így, mert a probléma kezelése, megoldása csak széleskörü összefogással valósulhat meg, amelyben a rendőrség a polgárőrségen kívül a lakosság együttmüködésére is számít. A lakosság részéről még nem érte el ez a jelenség azt az ingerküszöböt, amely automatikussá tenné a lakossági bejelentéseket. Tudatosítani kell az emberekben, hogy ezekkel a büncselekményekkel okozott károknak mindenki az elszenvedője, ezért mindenkinek érdeke a felelősök megtalálása felelősségre vonása. Ezen a területen a kapcsolatépítésben lehet fontos szerepe a polgárörségnek, mert tagjai jelen vannak a mindennapokban, helyben laknak. Lehetőségük van rá, hogy rálássanak a rendkívüli eseményekre. Azért meg kell jegyezni, hogy bizonyos körben mégis megnőtt az emberek bejelentési hajlandósága, aminek köszönhetően csökkentek bizonyos büncselekmények, pl.: a terménylopások, borospincék feltörése, borlopás. A cél az, hogy ez a bejelentési hajlandóság a környezetkárosításokra és minden környezetvédelemmel öszszefüggő káresetre is kiterjedjen, és további segítséggel, közremüködéssel is kiegészüljön a rendőrség irányába a hatékony fellépés érdekében.

A program végrehajtásának várható befejezését a 2020. év végére hirdették. Fökapitány Úr hogyan vélekedik erröl?

A Külterületek biztonsága, környezetünk védelme programot meghirdető résztvevők nem csupán egy kampánynak szánták azt, ezért teljesen biztos vagyok abban, hogy annak megvalósítása nem ér véget 2020-ban. Legfontosabb üzenete a figyelem-kiterjesztés a külterületek felé, amely egy hosszú távon is fenntartani kívánt cél.

Mi az Országos Rendőr-fökapitányság szerepe a program végrehajtásában? A rendőrségnek több fontos szerepe is van a végrehajtásban, többek között az, hogy az adatbázisa alapján rámutasson arra, melyek azok a területek, ahol a legnagyobb szükség van a beavatkozásra. Erősíti továbbá a polgárőrök és az 
egyéb önkormányzati, rendészeti feladatokat ellátó szervek közötti együttmüködést, betölt egyfajta koordinátori szerepet is. Ezeken túl pedig amennyiben szükséges, a tevékenységi területre vonatkozó jogszabályok módosítását, kiegészítését is kezdeményezi. Nagyon szeretném, ha nem csak a közfelfogásban elfogadott rendészeti, járőrözési, polgárőri tevékenységre korlátozódna a rendőrség részvétele. Szívesen részt veszünk kollégáinkkal a szélesebb figyelemfelkeltést célzó megmozdulásokban, kampányokban, fásítási programban, egyéb akciókban. Ezzel is hozzájárulva a környezettudatos magatartás erősítéséhez. Ehhez kapcsolódik az ORFK Közlekedésrendészet legújabb kampánya, amely a gépjármüvek szennyező anyag kibocsátásának mértékét szüri. A téli fütésszezon beköszöntével pedig aktuális kérdéssé válik a különböző, légszenynyezést okozó tüzelőanyagok használata. Ez egy olyan terület, ahol nem csak a bejelentés, figyelmeztetés lenne szükséges az érintettek részéről, hanem egyúttal segítségnyújtás is a káros anyagok kiváltására, hiszen ezekben az esetekben nem a szennyezést okozók megbüntetése a cél, hanem a szennyezés megelözése, jövőbeli elkerülése. Bízom benne, hogy a rendőrség továbbra is hatékony szerepet tölt be a jövőben a konferencián megfogalmazott célok megvalósításában, a hazánkat is érintő globális méretű problémák kezelésében, megoldásában.

\section{Nagy István agrárminiszter is elfogadta megkeresésünket, tőle a követke- ző válaszokat kaptuk kérdéseinkre a közösen meghirdetetett programmal kapcsolatban.}

Mi a közös program célja, szükségessége, milyen elözmények kötődnek hozzá? A magyar gazdák, agrárvállalkozások folyamatosan fejlesztenek, beruháznak a hazai és európai uniós támogatásokból, pályázati forrásokból és az állami kamattámogatás mellett felvett, kedvezményes hitelekből. A nagy értékủ beruházások, a modern gépek, eszközök, technológiák, az újonnan kiépülő mezőgazdasági infrastruktúra, a klímaváltozás kedvezötlen hatásait mérséklö öntözésfejlesztés keretében megépülő mütárgyak, öntözőrendszerek nagyobb védelmet igényelnek. Ehhez hasonlóan azok a fák, parkok, fasorok, erdők, ipari célú faültetvények is fokozott védelemre szorulnak, amelyek a most induló országos erdősítési, fásítási program keretében fogják gazdagítani Magyarország faállományát.

A polgárőrség jelenléte a kormányzati programok indulásánál, közremüködése a végrehajtásuk során, előmozdítja a kormányzati célok megvalósítását. A program célja a jogsértések - a zártkerti, szántóföldi, mezei, erdei lopások megelőzése, a tanyákon, külterületeken élők biztonságának garantálása, a gazdaságok, nagy értékü eszközök, üdülők védelme, tevékeny szerepvállalás a környezet- és természetvédelemben.
Miként határozná meg a program időtartamát az agrártárca részéröl? A program kialakításánál biztos alapot jelentett, hogy a rendőrség, a polgárörség és a megyék szervezésében lezajlottak már közel azonos tartalmú és célú eredményes programok az elmúlt húsz évben. Az összegyüjtött információk, tapasztalatok a megkezdett munka folytatására ösztönözték a polgárőrséget új célok kitüzésével együtt. A Külterületek biztonsága, környezetünk védelme 2019-2020 program idén indult és jövőre fejeződik be, de bízunk abban, hogy a következő években is folytatódhat.

Kik a program résztvevöi?

Az együttmüködés az Országos Rendőr-fökapitányság, az agrártárca és az Országos Polgárőr Szövetség, a megvalósulás szintjén a polgárőrök és a mezőőrök között jött létre, hogy a közösen felmutatott eredmények növeljék tovább az őrszolgálat és a polgárőrség társadalmi megbecsültségét, ösztönözzék további tagok jelentkezését, újabb őrszolgálatok és polgárőr egyesületek alapítását. Az Agrárminisztérium ágazati szakmai felügyelete alá jelenleg kilenc rendészeti feladatot ellátó őrszolgálat tartozik, amelynek tagjai a mezőőrök mellett, a hegyőrök, a természetvédelmi őrök, az önkormányzati természetvédelmi őrök, a halászati őrök, az erdővédelmi szolgálat tagjai, a hivatásos vadászok, az erdészeti szakszemélyzet és a jogosult erdészeti szakszemélyzet, valamint az élelmiszer-rendészet munkatársai. A mezei őrszolgálat rendészeti jellegű feladatokat ellátó szerv - a többi őrszolgálathoz hasonlóan. Az Agrárminisztérium, mint ágazati felelős a felsorolt kilenc őrszolgálata feletti felügyeletét a Belügyminisztériummal közösen gyakorolja.

Mi az Agrárminisztérium szerepe a programban?

Az Agrárminisztérium a költségek finanszírozásával támogatja a kezdeményezést. A megyénként kettőmillió forinttal kalkulált támogatási keretből a jelentősebb erdő- és mezőgazdasággal rendelkező megyék nagyobb részt kapnak. A szaktárca által elkülönített keret, összesen mintegy negyvenmillió forint, fedezi a mezőőri szolgálat ellátásával járó költségeket, továbbá lefedi a külterületek biztonságát, a termésbiztonságot szolgáló program forrás- és eszközigényét. Ezek a polgárör egyesületek müködési és üzemanyag költsége, drónok, éjjellátók, hőkamerák, távcsövek, valamint ruházat beszerzése, a programot kísérô kommunikáció finanszírozása, fotók, videók, TV- és rádió szpotok készítése, a Lovas Tagozat, a kutyás csoport támogatása.

Folytatódik-e a közös program a 2020. esztendö után?

A program eredményeit szemléletformálással tehetjük tartóssá. A hatékony bünmegelőzéshez, a külterületeken élők biztonságához, vagyontárgyaik védelmé- 
hez, a környezet- és természetkárosító, rossz beidegződések megváltoztatásához, az ökológiai egyensúly fenntartásához, a klímaváltozással járó negatív hatások elkerüléséhez ugyanis elengedhetetlen a társadalmi szemléletváltás. Célunk, hogy a rendőrség és az agrártárca, valamint a polgárőrök és a mezőőrök között létrejött együttmüködések, a közösen felmutatott eredmények növeljék az őrszolgálat és a polgárőrség társadalmi megbecsültségét, ösztönözzék további tagok jelentkezését, újabb őrszolgálatok és polgárőr egyesületek alapítását.

A körinterjú összegzéseként elmondható, hogy a program résztvevőinek válaszaiban megfogalmazott gondolatok sok esetben szinkronban vannak egymással. A jövőképet említve például, mindannyian kiemelték a társadalom szemléletváltásának fontosságát, illetve a kitüzött célok hosszú távon eredményes megvalósításának feltételeként említették a lakosság bevonását. Mind a polgárőrség, mind a rendőrség részéről felmerült annak megállapítása, hogy a települések elfogadható biztonsági szintjének köszönhetően, mindkét szervezet felszabaduló kapacitásával nagyobb figyelmet lehet szentelni a külterületeknek, természetesen a meghirdetett együttmüködés keretében, amely tulajdonképpen hosszú évtizedekre tekint vissza. Ezért lehetünk biztosak abban, hogy a most elinduló projekt és azzal együtt kifejezésre jutó, Magyarország egészét érintő célkitűzések előbb-utóbb maradéktalanul megvalósulnak, és ezzel sikerül hatékonyan megvédeni azokat a természeti értékeket, amelyek végeredményben mindannyiunk jólétét szolgálják. 